\title{
PUTUSAN PENGADILAN NEGERI PADANG NOMOR: 69/PDT.G/2009/PN.PDG TENTANG HIBAH WASIAT PERSPEKTIF HUKUM ISLAM
}

\author{
Suci Rahmawati \\ Univertsitas Islam NegeriImam Bonjol, thahirah_el_ayyubiyah@yahoo.com
}

\begin{tabular}{l|l|l|} 
Diterima: 21 Juli 2019 & Direvisi : 16 November 2019 & Diterbitkan: 30 Desember 2019 \\
\hline
\end{tabular}

\begin{abstract}
This article would explain the testament of the testamentary gift Number: 69/Pdt.G/2009/PN.Pdg., in the Padang District Court. As for the background of this research is the settlement of the will between the people of Islam, but decided by the district court, so there are some irregularities, both in terms of formal law and Islamic law. This research is a normative legal research with data analysis method in the form of content analysis. Based on the results of the decision are considered appropriate by the panel of judges who completed the case. Although there are no legal remedies from the parties against the decision of the district court judge, from the perspective of Islamic law the decision is still contrary to what should apply to people of Islam.
\end{abstract}

Keywords: District Court, Testamentary Gift, Islamic Law.

\begin{abstract}
Abstrak
Artikel ini menjelaskan tentang perkara bibah wasiat Nomor: 69/Pdt.G/2009/PN.Pdg., di Pengadilan Negeri Padang. Adapun latar belakang penelitian ini adalah adanya perkara wasiat antara orang yang beragama Islam, namun diputuskan oleh pengadilan negeri, sehingga menimbulkan beberapa kejanggalan, baik dari segi bukum formil maupun bukum Islam. Penelitian ini adalah penelitian bukum normatif dengan metode analisis data berupa analisis isi (content analysis). Berdasarkan basil penelitian diketabui bahwa putusan yang dibuat dinilai sudah tepat oleh majelis hakim yang menyelesaikan perkara tersebut. Meskipun tidak ada upaya banding yang dilakukan oleh para pibak yang berperkara terhadap putusan tersebut, namun hal ini tetap saja bertentangan dengan apa yang seharusnya diterapkan bagi orang yang beragama Islam.
\end{abstract}

Kata Kunci: Pengadilan Negeri, Hibah Wasiat, Hukum Islam.

\section{PENDAHULUAN}

Di Indonesia terdapat dua badan peradilan yang berwenang atas penyelesaian perkara perdata, yaitu peradilan umum dengan Pengadilan Negeri sebagai pengadilan tingkat pertama dan Pengadilan Tinggi Negeri sebagai pengadilan tingkat banding, serta peradilan agama dengan Pengadilan Agama sebagai pengadilan tingkat pertama dan Pengadilan Tinggi Agama sebagai pengadilan tingkat banding. Meskipun demikian, kedua badan peradilan tersebut memiliki perbedaan mengenai kewenangan absolut pengadilan.

Secara yuridis, Peradilan Umum sebagai salah satu pemegang kekuasaan kehakiman memiliki kewenangan untuk memeriksa, mengadili dan memutus perkara pidana dan perdata pada tingkat pertama untuk Pengadilan Negeri dan tingkat banding untuk Pengadilan Tinggi Negeri. ${ }^{1}$ Sedangkan Peradilan Agama, berdasarkan Undang-undang Nomor 7 Tahun 1989 jo Undang-undang Nomor 3 Tahun 2006 tentang Peradilan Agama mempunyai kewenangan untuk memeriksa, mengadili dan memutus perkara antara orang-orang yang beragama Islam di bidang perkawinan, kewarisan, wasiat, hibah, 2 Tahun 1986 tentang Peradilan Umum. 
wakaf, zakat, infak, sedekah dan ekonomi syari'ah. $^{2}$

Berdasarkan ketentuan tersebut diketahui bahwa segala bentuk perkara perdata yang dihadapi oleh orang-orang yang beragama Islam diselesaikan oleh Peradilan Agama, bukan Peradilan Umum. Namun, dalam realitanya masih terdapat perkara perdata antara orang Islam yang diselesaikan oleh Peradilan Umum, salah satunya adalah perkara hibah wasiat yang diputuskan oleh Pengadilan Negeri Padang dengan perkara Nomor: 69/Pdt.G/2009/PN.Pdg.

Perkara hibah wasiat tersebut diajukan oleh enam orang penggugat melawan dua orang tergugat yang sama-sama beragama Islam. Enam orang penggugat menyatakan diri sebagai ahli waris dari seorang pewaris yang bernama ALRB. Keseluruhan penggugat tersebut merupakan anak-anak kandung dari saudara-saudara kandung pewaris yang telah meninggal dunia sebelum meninggalnya pewaris. Sedangkan tergugat yang terdiri dari tergugat I adalah isteri pewaris, dan tergugat II merupakan pelaksana wasiat.

Pada positanya, para penggugat mengemukakan dua hal mengenai pengajuan gugatan tersebut ke Pengadilan Negeri Padang, yaitu berkenaan dengan hibah wasiat yang belum dilaksanakan dan harta yang diduga merupakan warisan dari pewaris yang tidak dicantumkan di dalam surat wasiat yang semestinya harus diselesaikan menurut ketentuan yang berlaku.

Harta yang telah dihibahwasiatkan adalah berupa tiga bidang tanah hak milik dengan bangunan yang berdiri diatasnya, serta saham perusahaan masing-masing sebanyak 50 $\%$ kepada tergugat I sebagai isteri pewaris dan kepada saudara-saudara kandung pewaris yang

2 Lihat Pasal 49 Undang-undang Nomor 7 Tahun 1989 tentang Peradilan Agama jo Pasal 49 Undang-undang Nomor 3 Tahun 2006 tentang Perubahan Undang-undang Nomor 7 Tahun 1989 tentang Peradilan Agama. dalam hal ini adalah orang tua kandung dari para penggugat yang keseluruhannya telah meninggal dunia sebelum meninggalnya pewaris.

Selanjutnya, harta yang diduga sebagai harta warisan yang belum dibagi selain yang dicantumkan dalam surat wasiat adalah berupa tiga bidang tanah hak milik lengkap dengan sertifikatnya. Dua bidang tanah yang dimaksud berlokasi di Kota Padang, dan satu bidang lainnya berlokasi di Kabupaten Pesisir Selatan.

Adapun putusan hakim Pengadilan Negeri Padang dalam perkara tersebut adalah mengabulkan gugatan penggugat berkenaan dengan pemberian hibah wasiat sebanyak $50 \%$ dari modal perusahaan dan tanah hak milik sesuai dengan apa yang tercantum dalam akta wasiat.

Putusan hakim terkait perkara di atas dinilai menciderai aturan hukum mengenai kewenangan absolut pengadilan. Selain itu, terdapat kekeliruan lain mengenai pelaksanaan hibah wasiat tersebut. Pertama, yaitu mengenai ketentuan bahwa hibah wasiat dilaksanakan setelah pewasiat meninggal dunia, akan tetapi dalam kasus ini penerima wasiat telah meninggal lebih dahulu dari penerima wasiat. Seharusnya berdasarkan ketentuan pasal 899 Kitab Undang-undang Hukum Perdata ${ }^{3}$, selanjutnya disingkat dengan KUH Perdata, hibah wasiat tersebut menjadi batal. Kedua, yaitu berkenaan dengan pemberian hibah

${ }^{3} \mathrm{KUH}$ Perdata disebut juga dengan Burgerlijk Wetboek (BW), merupakan produk pemerintah Hindia Belanda yang berlaku di Indonesia berdasarkan atas asas konkordansi, yaitu asas yang menyatakan bahwa hukum yang berlaku di Indonesia sama dengan ketentuan hukum yang berlaku di negeri Belanda. KUH Perdata terdiri dari empat buku. Buku I tentang Hukum Orang, Buku II tentang Hukum Benda, Buku III tentang Perikatan, dan Buku IV tentang Pembuktian dan Daluwarsa. Hingga saat ini Indonesia masih belum memiliki KUH Perdata sendiri. Meskipun demikian, terdapat beberapa ketentuan di dalam KUH Perdata atau BW tersebut yang telah dicabut dan atau diganti karena sudah adanya produk undang-undang milik pemerintah Indonesia, seperti tentang perkawinan. Lihat Salim HS., Pengantar Hukum Perdata Tertulis (BW), (Jakarta: Sinar Grafika, 2005). Cet-3., 3-4 
wasiat lebih dari $1 / 3$ harta peninggalan pewasiat. Hal ini bertentangan dengan ketentuan hukum Islam, berdasarkan hadis Rasulullah SAW., sebagai berikut:

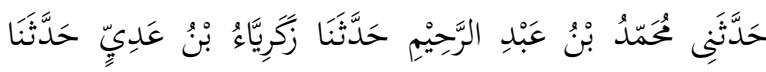

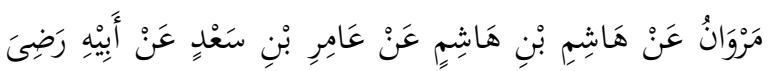

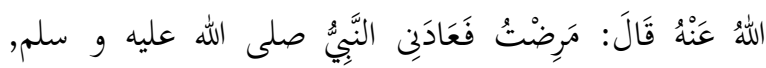

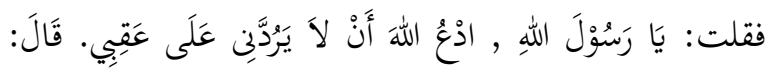

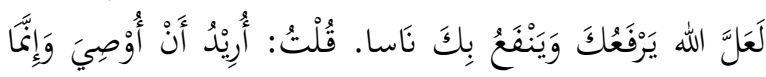

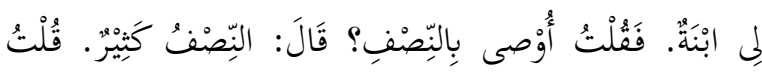

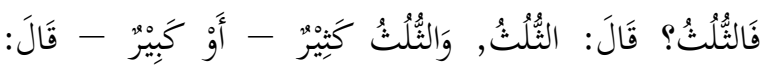

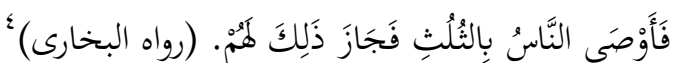
"Telah bercerita kepadaku Mubammad ibn 'Abd alRahim, telah menceritakan kepada kami Zakariyya' ibn 'Adiy, telah menceritakan kepada kami Marwān dari Hāsyim ibn Hāsyim dari 'Āmr ibn Sa'ad dari ayahnya ra., ia berkata: Aku sakit, lalu Nabi SAW., menjengukeku. Kemudian aku katakan: Ya Rasulullah, mohonkanlah kepada Allah agar Dia tidak mengembalikan aku kepada keadaan sebelumnya (negeri kafir). Beliau bersabda: Semoga Allah mengangkat derajatmu dengan memberikan manfaat kepada manusia melalui dirimu. Aku berkata: Aku ingin berwasiat, sedangkan aku memiliki seorang anak perempuan. Maka aku bertanya apakah aku boleh berwasiat dengan setengah bartaku? Beliau bersabda: Setengab itu banyak. Aku tanyakan lagi: Sepertiganya? Beliau bersabda: Ya, sepertiga. Sepertiga itu banyak atau besar. Dia (Sa'ad) berkata: Maka kemudian orang-orang berwasiat sepertiga dan beliau (Rasulullab $S A W$ ) membolebkannya." (HR. Bukbāri)

Perkara hibah wasiat Nomor: 69/Pdt.G/2009/PN.Pdg., memang telah berkekuatan hukum tetap dan tidak ada upaya banding yang dilakukan. Artinya, para pihak menerima hasil putusan hakim Pengadilan Negeri Padang dalam perkara hibah wasiat ini. Namun, persoalannya adalah pada satu sisi memang tidak terdapat upaya hukum dari para pihak yang berperkara, dan putusan pun telah berkekuatan hukum tetap. Namun, pada sisi

4 Abū Abdullah Muhammad ibn Ismā̄̄l alBukhārī, al-Jamì al-Saḥịh, vol. 2, (Mesir: Maṭba'ah alSalafiyyah, 1403 H). 287 lain hibah wasiat antara orang-orang yang beragama Islam telah diatur sedemikian rupa dan merupakan pertanggungjawab secara vertika antara manusia dengan Allah serta secara horizontal antar-sesama manusia.

Berangkat dari latar belakang tersebut di atas, penelitian ini bermaksud untuk menganalisis putusan hakim Pengadilan Negeri Padang Nomor: 69/Pdt.G/2009/PN.Pdg., tentang hibah wasiat ini dan meninjaunya dari sudut pandang hakim yang memutuskan perkara terkait dan dari sudut pandang hukum Islam.

Adapun tujuan dari penelitian ini adalah untuk mengungkap argumentasi hakim Pengadilan Negeri mengabulkan perkara hibah wasiat Nomor: 69/Pdt.G/2009/PN.Pdg., dan untuk memaparkan penyelesaian perkara hibah wasiat di Pengadilan Negeri Padang Nomor: 69/Pdt.G/2009/PN.Pdg ditinjau dari hukum Islam.

Selanjutnya, kegunaan penelitian ini secara teoritis adalah untuk menambah wawasan intelektualitas yang luas terkait perkara hibah wasiat antara orang-orang yang beragama Islam dan membantu terselenggaranya hukum yang adil dan selaras dengan ketentuan hukum yang berlaku, baik hukum Islam maupun hukum yang berlaku di Indonesia. Sedangkan secara praktis, penelitian ini diharapkan dapat memberikan kontribusi dalam penerapan hukum Islam, khususnya berkenaan dengan persoalan hibah wasiat, serta menjadi sumbangan pemikiran dan sebagai saran untuk mengarahkan pihak-pihak terkait, yang dalam hal ini pihak yang berperkara, konsultan hukum dan hakim pengadilan.

\section{METODE PENELITIAN}

Jenis penelitian yang digunakan adalah penelitian hukum normatif (normative legal research $)^{5}$, yaitu kajian terhadap sumber-sumber

${ }^{5}$ Penelitian hukum normatif disebut juga dengan penelitian hukum doktriner, karena dilakukan dan 
yang tersedia dengan mengumpulkan, membaca dan menelaah buku-buku, serta menelusuri putusan-putusan Pengadilan Negeri Padang berkaitan dengan permasalahan yang dibahas. Kemudian didukung dengan hasil penelitian di lapangan berupa hasil wawancara dengan majelis hakim yang menerima, memeriksa dan mengadili perkara hibah wasiat

Nomor: 69/Pdt.G/2009/PN.Pdg., untuk selanjutnya ditinjau berdasarkan hukum Islam.

Pendekatan yang digunakan dalam penelitian ini adalah melalui pendekatan perundang-undangan (statute approach), yaitu Kompilasi Hukum Islam dan KUH Perdata yang berkaitan dengan hibah wasiat dan atau wasiat.

Adapun jenis data yang digunakan dalam penelitian ini adalah data sekunder berupa peraturan perundang-undangan dan register perkara yang berkaitan dengan perkara hibah wasiat antara orang-orang yang beragama Islam di Pengadilan Negeri Padang. Sedangkan sumber datanya terdiri bahan hukum primer berupa putusan hakim Pengadilan Negeri Padang Nomor: 69/Pdt.G/2009/PN.Pdg., tentang perkara hibah wasiat, bahan hukum sekunder berupa peraturan perundang-undangan, buku-buku dan kitab-kitab yang berkaitan dengan masalah yang penulis teliti, dan bahan hukum tersier, yaitu bahan hukum yang memberikan penjelasan dan petunjuk terhadap bahan hukum primer dan bahan hukum sekunder, seperti Kamus Hukum, Ensiklopedia Hukum Islam, dan Kamus Bahasa Arab.

Untuk terkumpulnya data yang dibutuhkan, digunakan teknik berupa riset pustaka dan wawancara. Riset pustaka dilaksanakan dengan melakukan penelusuran putusan pada direktori putusan di website Mahkamah Agung Republik Indonesia dan

ditujukan hanya pada peraturan-peraturan yang tertulis. (Lihat Bambang Sunggono, Metode Penelitian Hukum, (Jakarta : Raja Grafindo Persada, 2005). 27 register perkara di Pengadilan Negeri Padang berkenaan dengan perkara hibah wasiat yang diputuskan oleh Pengadilan Negeri Padang. Adapun wawancara dilakukan melalui via telepon dan chatting dengan hakim yang menerima dan memutuskan perkara Nomor: 69/Pdt.G/2009/PN.Pdg., tentang hibah wasiat di Pengadilan Negeri. Kemudian, untuk mendukung pertimbangan dari hakim Pengadilan Negeri, juga dilakukan wawancara dengan hakim Pengadilan Agama berkenaan dengan kewenangan mengadili perkara perdata, yang dalam hal ini perkara hibah wasiat oleh pengadilan.

Selanjutnya, setelah semua data terkumpul, data kemudian dianalisis menggunakan metode content analysis ${ }^{6}$, yaitu analisis data dilakukan terhadap sejumlah data putusan yang telah dikumpulkan, kemudian dianalisis secara normatif kualitatif untuk mendapatkan hasil penelitian yang deskriptif analisis.

Adapun langkah-langkah analisis putusan yang dilakukan dalam penelitian ini adalah dengan menjelaskan duduk perkara yang menjadi dasar putusan hakim dalam penyelesaian perkara hibah wasiat Nomor: 69/Pdt.G/2009/PN.Pdg., kemudian menelaah diktum-diktum dalam pertimbangan putusan hakim serta menganalisis dasar hukum yang digunakan hakim dalam memutuskan perkara. Kemudian putusan dianalisis dari aspek hukum materil, hukum formil, dan penalaran hukum dan/atau alasan serta argumentasi hakim. Selanjutnya, data yang didapat, yang dalam hal ini berkenaan dengan perkara hibah wasiat, ditelaah berdasarkan ketentuan hukum Islam. Terakhir, data dianalisis serta ditarik

${ }^{6}$ Menurut Holsti sebagaimana yang dikutip oleh Satori dan Komariah, content analysis atau analisis isi adalah suatu metode yang digunakan untuk menarik kesimpulan penelitian melalui usaha menemukan karakteristik pesan dan dilakukan secara objektif dan sistematis. Lihat Djam'an Satori dan Aan Komariah, Metodologi Penelitian Kualitatif, (Bandung: Alfabeta, 2009). 157 
kesimpulan mengenai putusan hakim dalam perkara hibah wasiat Nomor: 69/Pdt.G/2009/PN.Pdg., dan kemudian hasil penelitian dipaparkan secara deskriptif analisis.

\section{PENYELESAIAN PERKARA HIBAH WASIAT NOMOR: 69/PDT.G/2009/PN.PDG., $\quad$ DI PENGADILAN NEGERI PADANG}

Konsep hibah wasiat ini secara tekstual hanya terdapat dalam ketentuan KUH Perdata. Adapun dalam literatur hukum Islam istilah hibah wasiat tersebut tidak dikenal. Akan tetapi, secara yuridis dapat diketahui bahwa hibah wasiat dalam Islam adalah wasiat ${ }^{7}$. Hal ini dapat dipahami berdasarkan kesamaan proses pelaksanaannya dalam ketentuan fikih, KHI pasal 171 huruf $\mathrm{f}$ dan pasal 874-879 KUH Perdata, yaitu disandarkan kepada kematian pewasiat. $^{8}$

Hibah wasiat dalam KUH Perdata disebut juga dengan istilah legaat. Hibah wasiat merupakan bagian dari wasiat jika ditinjau dari segi isinya, yaitu wasiat pengangkatan ahli waris (erfstelling) dan wasiat hibah atau hibah wasiat (legaat). ${ }^{9}$

Wasiat dengan berisi legaat atau hibah wasiat, yaitu suatu penetapan wasiat secara

7 Wasiat dalam literatur fiqh diartikan oleh ulama, antara lain yang dikemukakan oleh Syeikh Sayyid Sabiq, yaitu "penyerahan kuasa secara khusus kepada seseorang yang berlaku setelah kematian". Lihat Syaikh Sayyid Sābiq, Fiqh al-Sunnah, vol. III, (Beirut: Dār al-Fikr, 2007), 1000. Adapun dalam KHI, wasiat diartikan sebagai "pemberian suatu benda dari pewaris kepada orang lain atau lembaga yang akan berlaku setelah pewaris meninggal dunia". Lihat Pasal 171 huruf f KHI. Sedangkan dalam KUH Perdata, wasiat adalah "sebuah akta berisi pernyataan seseorang tentang apa yang dikehendakinya terjadi setelah ia meninggal, yang dapat dicabut kembali olebnya”. Lihat ketentuan Pasal 875 KUH Perdata.

8 Mo Syamsul Mu'arif, "Perbandingan Wasiat dalam Perspektif Kompilasi Hukum Islam (KHI) dan Burgerlijk Wetboek (BW)", Jurnal Tafaqquh: Jurnal Penelitian dan Keislaman, vol.3 No.2, (Desember 2015). 107

${ }^{9}$ I Gusti Ayu Putu Oka Cahyaning Mustika Sari, et.al., "Peralihan Hak Atas Tanah Berdasarkan Hibah Wasiat oleh Pelaksana Wasiat", Acta Comitas: Jurnal Hukum Kenotariatan, vol .III No.1, (April 2018). 165 khusus dari pewasiat mengenai pemberian beberapa barang tertentu atau hak pakai dari sebagian atau seluruh harta peninggalan pewasiat kepada satu orang atau lebih. ${ }^{10}$

Adapun dalam perspektif hukum Islam, wasiat secara etimologi berasal dari bahasa Arab "wasa" yang berarti menyampaikan atau memberi pesan atau pengampuan. ${ }^{11}$ Kata "wasiat" setidaknya disebutkan sebanyak $32 \mathrm{kali}^{12}$ di dalam Alquran, diantaranya memiliki makna memerintahkan $^{13}$, mewajibkan ${ }^{14}$ dan mensyari'atkan ${ }^{15}$.

Sedangkan wasiat secara terminologi, terdapat beberapa pendapat ulama. Menurut ulama Mazhab Syafi'i, wasiat adalah:

$$
\text { الوَصِيَّة تبرِع بَحقِّ مُضَاف إِلَى مَا بَعْدَ المؤتِ. } 17
$$

10 Lihat ketentuan pasal 957 KUH Perdata

11 Ahmad Warson Munawwir, Kamus ArabIndonesia, (Surabaya: Pustaka Progressif, 1997). ed-2, cet14, 1563

12 Hitungan ini berdasarkan pencarian dengan asal kata wasiat, yaitu "wașa". Adapun jumlah kata "wasiat" (mașdar dari kata "wașa") itu sendiri di dalam al-Qur'an disebutkan sebanyak 8 kali, yaitu pada surat al-Baqarah 2 kali, pada surat al-Nisā' 5 kali, dan pada surat al-Māidah 1 kali. Lihat Muhammad Fuād 'Abd alBāqī, Mu'jam al-Mufahras li al-alfäz al-Qur'ān al-Karim, (Mesir: Maṭba'ah Dār al-Kutub al-Mișriyyah, 1364 H). 752

13 Wasiat dalam arti memerintahkan terdapat dalam surat al-Nisā' ayat 131, sebagai berikut:

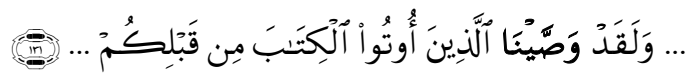

Artinya: “... dan sungguh kami telah memerintahkan kepada orang-orang yang diberi Kitab sebelum kamu...”

14 Arti ini terdapat dalam surat al-'Ankabūt ayat 8, sebagai berikut:

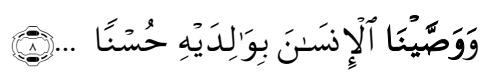

Artinya: "Dan kami wajibkan manusia (berbuat) kebaikan kepada dua orang ibu-bapaknya..."

15 Wasiat dengan artian "mensyari'atkan" terdapat dalam surat al-Nisā' ayat 11, yaitu:

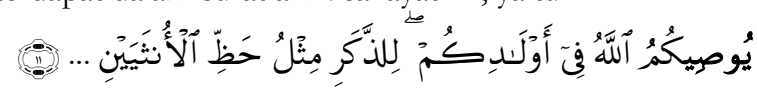

Artinya: "Allah mensyari'atkan bagimu tentang (pembagian pusaka untuk) anak-anakmu, yaitu : babagian seorang anak lelaki sama dengan bahagian dua orang anak perempuan..."

16 Abū Bakr ibn Muhammad Zain al-'Ābidīn Syațā, I'ānah al-Tālibin, vol. 3, (t.tp: Dār Iḥyā' al-Kutub 
"Wasiat adalah suatu perbuatan baik dengan memberikan bak yang pelaksanaannya berlaku setelah wafat (pewasiat)."

Menurut ulama Mazhab Hanafi, definisi wasiat adalah sebagai berikut:

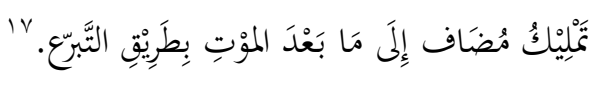

"Pemberian hak milik setelah pewasiatnya meninggal dunia dengan jalan sukarela."

Wasiat perspektif ulama Mazhab

Maliki adalah:

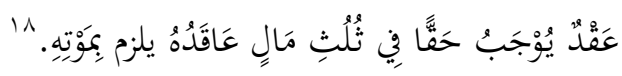

"Transaksi yang mengharuskan (penerima wasiat) mendapatkan 1/3 dari harta (peninggalan pewasiat) yang pelaksanaannya berlaku setelab kematian pewasiat."

Secara terminologi ulama Mazhab Hanbali memahami wasiat sebagai berikut:

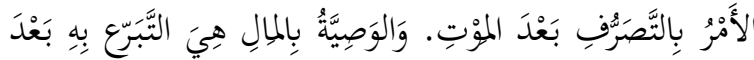

$$
\begin{aligned}
& \text { المؤتِ. } 19
\end{aligned}
$$

"Transaksi pemindahan bak milik yang berlaku setelah wafat (pewasiat). Adapun wasiat dengan harta adalah perbuatan baik yang dilakukan setelah meninggal dunia (pewasiat)."

Menurut Syaikh Sayyid Sābiq, wasiat adalah:

al-'Arabiyyah, tt), 199. Lihat juga Syams al-Dīn Muhammad ibn al-Khațīb al-Syarbainī, Mughnì alMuhtäj, Juz III, (Beirut: Dār al-Ma'rifah, 1997), 52. Lihat juga 'Abd al-Raḥmān al-Jazìrī, Kitāb al-Fiqh 'alà alMazābib al-Arba'ah, vol. III, (Beirut: Dār al-Kutub al'Ilmiyyah, 2002). 278

17 Imām 'Alāuddīn Abī Bakr ibn Mas'ūd alKasānī al-Hanafî, Badāì al-Sanāì' fì Tartỉb al-Syaräì', Juz X, (Beirut: Dār al-Kutub al-'Tlmiyyah, 2002). 468. Lihat juga 'Abd al-Raḥmān al-Jazìrī, Kitäb al-Fiqh 'alā alMąāabib al-Arba'ah, 277

18 Abū Bakr ibn Husain al-Kasnāwī, Aṣal alMadārik: Syarh Irsyād al-Sälike fì Fiqh Imām al-A'immab Mālik, Juz III, (Beirut: Dār al-Fikr, tt), 271. Lihat juga 'Abd al-Raḥmān al-Jazìrī, Kitāb al-Fiqh 'alā al-Maz̃äbib alArba'ah, 277

19 Abū Muhammad 'Abdullah ibn Aḥmad ibn Muhammad ibn Qudāmah al-Maqdisī, al-Muqni’ fì Fiqh al-Imäm Ahmad ibn Hanbal al-Syaibānī, (Jeddah: Maktabah al-Sawādī li al-Tauzì, 2000), 249. Lihat juga Abū Muhammad 'Abdullah ibn Ahmad ibn Muhammad ibn Qudāmah al-Maqdisī, al-Mughnì, vol. VIII, (Riyaḍ: Dār ‘Ālim al-Kutub, 1997). 389

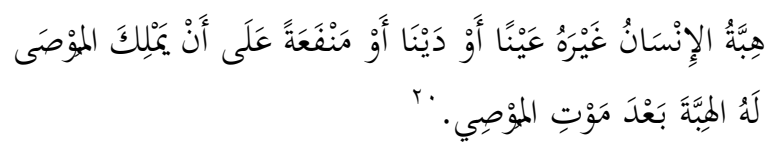

"Pemberian seseorang kepada orang lain berupa harta benda, butang, atau manfaat, agar penerima wasiat memiliki pemberian tersebut setelah pewasiat meninggal dunia."

Berdasarkan definisi yang dikemukakan oleh ulama di atas dapat dipahami bahwa ulama memberikan penekanan mengenai pelaksanaan wasiat yang telah dibuat oleh pewasiat berlaku setelah pewasiat meninggal dunia. Hal inilah yang semakin memberikan petunjuk bahwa hibah wasiat dalam KUH Perdata adalah wasiat itu sendiri.

Selanjutnya, sebelum dibahas lebih lanjut mengenai perkara hibah wasiat Nomor: 69/Pdt.G/2009/PN.Pdg., ini, perlu diketahui bahwa berdasarkan penelusuran penulis, baik pada register perkara perdata di Pengadilan Negeri Padang Kelas I.A maupun pada Direktori Putusan Mahkamah Agung yang memuat putusan-putusan dari pengadilan tersebut, tidak ditemukan pengelompokan perkara dengan keterangan "Hibah Wasiat".

Pada register perkara perdata di Pengadilan Negeri Padang Kelas I.A, penulis menemukan perkara Nomor: 69/Pdt.G/2009/PN.Pdg., tersebut dengan keterangan "Bagian Tanah". Menariknya, pada Direktori Putusan Mahkamah Agung perkara tersebut justru dikategorikan dalam perkara perdata "Waris". Namun, karena di dalam salinan putusan itu disebutkan bahwa perkara ini merupakan tuntutan atas harta hibah wasiat dan harta warisan yang belum dibagikan, maka penulis menempatkan perkara ini sebagai perkara hibah wasiat.

\section{Perkara}

Nomor:

69/Pdt.G/2009/PN.Pdg., tersebut tergolong perkara yang unik dan cukup menarik. Pada satu sisi perkara itu merupakan perkara hibah

20 Syaikh Sayyid Sābiq, Fiqh al-Sunnah, vol. III, 998 
wasiat dengan objeknya berupa tanah dan hak kepemilikan saham, namun di satu sisi juga berkaitan dengan harta warisan, karena kedudukan penggugat sebagai ahli waris, bukan sebagai penerima hibah wasiat yang tercantum di dalam surat wasiat.

Untuk lebih jelasnya, berikut dipaparkan lebih jelas mengenai perkara hibah wasiat Nomor: 69/Pdt.G/2009/PN.Pdg., baik dari sudut pandang majelis yang memutuskan perkara tersebut maupun dari sudut pandang hukum Islam.

\section{PANDANGAN HAKIM PENGADILAN NEGERI PADANG TERHADAP PUTUSAN 69/PDT.G/2009/PN.PDG}

Berangkat dari salinan putusan Pengadilan Negeri Padang yang meguraikan mengenai duduk perkara hibah wasiat Nomor: 69/Pdt.G/2009/PN.Pdg., penulis kemudian melakukan wawancara dengan majelis hakim yang memeriksa dan memutuskan perkara tersebut. Pembahasan dalam wawancara tersebut adalah perkenaan dengan dua hal, yaitu mengenai kewenangan absolut pengadilan dan pelaksanaan hibah wasiat antara orang-orang beragama Islam sebagai pihak berperkara dalam perkara Nomor: 69/Pdt.G/2009/PN.Pdg., itu.

Pertama, mengenai kewenangan absolut pengadilan dalam perkara hibah wasiat Nomor: 69/Pdt.G/2009/PN.Pdg., Jon Effreddi sebagai Hakim Anggota dalam perkara terkait mengatakan bahwa perkara tersebut berkaitan dengan kepemilikan modal CV. XXX, dimana Penggugat sebagai komanditer $^{21}$ dan Tergugat sebagai pengurus. Hal tersebut menjadi pertimbangan bagi majelis hakim menolak eksepsi kewenangan

21 Komanditer adalah peserta persekutuan dagang dengan memberikan sebagian modal saja tanpa turut menjalankan perusahaan tersebut. Lihat Departemen Pendidikan Nasional, Kamus Bahasa Indonesia, (Jakarta: Pusat Bahasa, 2008), 793 mengadili yang diajukan oleh Para Tergugat dalam putusan sela. ${ }^{22}$

Berdasarkan argumentasi hakim tersebut, diketahui bahwa ia sangat meyakini perkara Nomor: 69/Pdt.G.2009/PN.Pdg., adalah mutlak kewenangan Pengadilan Negeri tanpa melihat adanya unsur hibah wasiat antara orang-orang beragama Islam sebagai pihak yang berperkara.

Akan tetapi, jika dicermati dari fakta persidangan terlihat bahwa penggugat bukan berkedudukan sebagai komanditer sebagaimana yang disampaikan oleh Jon, namun berkedudukan sebagai ahli waris dari saudarasaudara pewasiat yang telah meninggal lebih dahulu dari pewasiat. Adapun yang berkedudukan sebagai komanditer adalah pewasiat, tergugat I (isteri pewasiat) dan $\mathrm{FH}$ yang merupakan rekan dari keduanya. ${ }^{23}$

Kemudian, wawancara dilakukan dengan majelis hakim lainnya dalam perkara Nomor: 69/Pdt.G.2009/PN.Pdg., yaitu Sapta Diharja. Ia mengemukakan bahwa putusan majelis hakim terkait penolakan eksepsi tergugat mengenai kewenangan absolut pengadilan sudah tepat. Hal ini dikaitkan dengan ketentuan pasal 49 UU Nomor 3 Tahun 2006 tentang Peradilan Agama.

Pada pasal itu tertera bahwa dalam kewenangan pengadilan agama hanya tertera perkara "hibah" dan "wasiat", tidak tertera "hibah wasiat", sehingga perkara Nomor: 69/Pdt.G/2009/PN.Pdg., adalah murni kewenangan dari pengadilan negeri. Di samping itu, Sapta juga mengatakan bahwa hakim harus memegang prinsip ius curia novit, yaitu hakim dianggap mengetahui hukum dan

22 Jon Effreddi, Majelis Hakim dalam Perkara Nomor 69/Pdt.G/2009/PN.Pdg., pada Pengadilan Negeri Padang Kelas IA (sekarang bertugas di Pengadilan Negeri Cilacap), Wawancara (via chatting melalui aplikasi $W$ hats $A p p$ ), tanggal 29 Mei 2018, pukul 20.50 WIB

23 Vide replika Tergugat dalam pokok perkara pada salinan putusan Nomor: 69/Pdt.G/2009/PN.Pdg, 15-16 
tidak boleh menolak perkara yang diajukan kepadanya. $^{24}$

Terkait argumentasi kedua majelis hakim dalam perkara Nomor: 69/Pdt.G/2009/PN.Pdg., penulis kemudian melakukan studi perbandingan dengan hakim pengadilan agama terkait kewenangan mengadili perkara hibah wasiat tersebut. Pada kesempatan tersebut penulis mewawancarai hakim junior, yaitu Fathur Rizqi dan hakim senior, yaitu Kastel Bahri.

Fathur mengemukakan bahwa ketentuan hibah wasiat secara yuridis memang tidak tertulis dalam kewenangan mengadili peradilan agama, namun ia menilai bahwa itu hanya merupakan persoalan redaksi undangundang saja. Inti dari hibah wasiat tersebut sama dengan wasiat yang terdapat dalam ketentuan hukum Islam. Dan terlepas dari hal tersebut, asas personalitas keislaman tidak boleh dikesampingkan ketika para pihak dalam perkara perdata adalah antara orang-orang beragama Islam. ${ }^{25}$

Argumen serupa juga disampaikan oleh Kastel. Ia mengatakan bahwa hibah wasiat adalah wasiat itu sendiri. Apabila perkara tersebut diajukan oleh-orang beragama Islam, maka hal ini semakin menguatkan bahwa yang berwenang untuk memeriksa dan memutuskan perkara tersebut adalah pengadilan agama, bukan pengadilan negeri. Hal ini telah diatur secara jelas dalam pasal 25 ayat (3) UU Nomor 48 Tahun 2009 tentang Kekuasaan Kehakiman jo pasal 49 UU Nomor 3 Tahun 2006 tentang Perubahan UU Nomor 7 Tahun 1989 tentang Peradilan Agama. ${ }^{26}$

24 Sapta Diharja, Majelis Hakim dalam Perkara Nomor: 69/Pdt.G/2009/PN.Pdg., pada Pengadilan Negeri Padang Kelas IA (sekarang bertugas di Pengadilan Negeri Ciamis), Wawancara (via telepon), tanggal 18 Juni 2018, pukul 19.56 WIB s/d 20.15 WIB

25 Fathur Rizqi, Hakim Pengadilan Agama Tembilahan, Wawancara, (via chatting melalui aplikasi Whats App), tanggal 26 Juli 2018, pukul 21.42 WIB

26 Kastel Bahri, Hakim Pengadilan Agama Bukittinggi, Wawancara (di Tabek Pariangan Batusangkar
Berdasarkan argumentasi majelis hakim yang memeriksa dan memutuskan perkara Nomor: 69/Pdt.G/2009/PN.Pdg., dan membandingkannya dengan argumentasi hakim Pengadilan Agama terkait kewenangan mengadili pengadilan, dapat disimpulkan bahwa letak persoalan ini adalah berkenaan dengan pemahaman hakim mengenai kata "hibah wasiat". Akibatnya, hal itu berdampak kepada pertimbangan hakim dalam menyelesaikan perkara hibah wasiat Nomor: 69/Pdt.G/2009/PN.Pdg.

Menurut penulis, pada dasarnya hakim Pengadilan Negeri yang memeriksa perkara Nomor: 69/Pdt.G/2009/PN.Pdg., memiliki pertimbangan yang sesuai dengan redaksi dalam ketentuan pasal 49 UU Peradilan Agama serta pemahaman yang kuat mengenai prinsip ius curia novit dalam hukum acara perdata yang mesti dipegang oleh hakim. Namun, hal tersebut belum dirasa cukup untuk memutuskan bahwa perkara Nomor: 69/Pdt.G/2009/PN.Pdg., adalah merupakan kewenangan dari Pengadilan Negeri Padang Kelas I.A.

Hakim memang dianggap mengetahui semua hukum, sehingga ia tidak boleh menolak perkara yang diajukan kepadanya. Namun, masing-masing peradilan memiliki kompetensi masing-masing, sehingga akan tercapai ketertiban dalam pelaksanaan kekuasaan kehakiman. Di samping itu, majelis hakim sudah sepatutnya memperhatikan asas personalitas keislaman yang terkandung di dalam UU Nomor 3 tentang Perubahan UU Nomor 7 tentang Peradilan Agama. Selanjutnya, terlepas dari hal tersebut yang paling penting adalah "lex specialist derogate legi generalis", hukum yang bersifat khusus mengenyampingkan hukum yang bersifat umum.

Kedua, mengenai pelaksanaan hibah wasiat dalam perkara hibah wasiat Nomor:

(kediaman Bapak Kastel)), tanggal 28 Juli 2018, pukul 17.25 WIB 
69/Pdt.G/2009/PN.Pdg., dalam duduk perkara yang dipaparkan dalam salinan putusan, terlihat secara jelas bahwa hibah wasiat yang tertuang dalam Akta Wasiat Nomor XXX Tahun 2000 diberikan kepada Tergugat I selaku isteri sah pewasiat, dan kepada Para Penggugat yang dalam hal ini adalah ahli waris pengganti dari penerima sah hibah wasiat tersebut, yaitu almarhum enam orang saudara kandung pewasiat yang telah meninggal dunia lebih dahulu dari pewasiat.

Hibah wasiat pelaksanaannya adalah setelah pewasiat/pewaris meninggal dunia. Jika penerima wasiat lebih dahulu meninggal dari pewasiat, maka seharusnya hibah wasiat tersebut menjadi batal demi hukum. Terdapat dua ketentuan yang termaktub di dalam KUH Perdata yang menunjukkan hal tersebut, yaitu ketentuan pasal 899 dan pasal $879 \mathrm{KUH}$ Perdata.

Pasal 899 KUH Perdata menyebutkan bahwa untuk menikmati sesuatu dari suatu surat wasiat, seseorang harus telah ada tatkala pewasiat meninggal dunia. Sedangkan pasal 879 KUH Perdata menerangkan bahwa tidak ada istilah penggantian ahli waris dalam pelaksanaan hibah.

Menyikapi kedua pasal tersebut, penulis kemudian melakukan wawancara dengan Sapta, hakim yang memeriksa dan memutuskan perkara hibah wasiat Nomor: 69/Pdt.G/2009/PN.Pdg. Menurutnya, kalimat "seseorang harus telah ada" dalam ketentuan pasal 899 KUH Perdata itu dapat dipahami dengan "sudah ada pada saat surat wasiat tersebut dibuat". Adapun mengenai pasal $879 \mathrm{KUH}$ Perdata, ia memahami bahwa hal itu berkenaan dengan hibah pengangkatan ahli waris, sehingga berbeda dengan hibah wasiat yang memang harus ditunaikan sebagaimana yang termaktub dalam akta wasiat. Kemudian, ia menambahkan bahwa sejatinya majelis hakim hanya ingin mengabulkan amanat pewasiat/pewaris yang telah dituangkan dalam Akta Wasiat Nomor XXX Tahun 2000. ${ }^{27}$

Menurut analisa penulis, berdasarkan dua ketentuan tersebut di atas, maka seharusnya secara de jure, hibah wasiat menjadi batal. Sehingga apabila ingin dilakukan pembagian atas harta peninggalan Pewaris, maka lebih tepatnya diselesaikan dengan proses waris. Namun, dalam fakta persidangan majelis lebih memahami perkara tersebut sebagai sengketa pelaksanaan wasiat, meskipun majelis mengakui bahwa dalam perkara tersebut juga terdapat perkara warisan Pewaris yang belum dibagikan. ${ }^{28}$

Selain itu, terdapat satu amar putusan hakim pada perkara Nomor: 69/Pdt.G/2009/PN.Pdg., yang dinilai menyalahi kompetensi Peradilan Umum, yaitu menetapkan ahli waris dari pewaris yang seluruhnya beragama Islam. Penyelesaian tersebut jelas merupakan domain dari Peradilan Agama, bukan Peradilan Umum. ${ }^{29}$

Berdasarkan hal tersebut di atas, penulis memahami bahwa sesungguhnya pemahaman hakim terhadap suatu ketentuan dalam UU mempengaruhi pertimbangan dan putusannya. Di samping itu, penulis berasumsi bahwa penyelesaian perkara hibah wasiat Nomor 69/Pdt.G/2009/PN.Pdg., di Pengadilan Negeri masih dibayang-bayangi oleh sejarah Peradilan Agama di Indonesia. Tahun 2009 dinilai sebagai masa transisi berdirinya Peradilan Agama sebagai salah satu badan peradilan yang diakui, sejajar, serta dapat berdiri sendiri tanpa intervensi dari badan peradilan lainnya di Indonesia, khususnya Peradilan Umum. Hal ini agaknya masih memberikan pengaruh bagi hakim dalam menyelesaikan perkara yang secara yuridis memang hanya tertulis dalam salah satu

${ }^{27}$ Sapta Diharja, Wawancara.

${ }^{28}$ Hal ini dapat disimpulkan dari Putusan Sela Perdata Nomor 69/Pdt.G/2009/PN.Pdg, 17-16

29 Vide amar putusan judex factie Nomor 69/Pdt.G/2009/PN.Pdg., dalam pokok perkara, 37 
sumber hukum Peradilan Umum, yaitu KUH Perdata.

\section{PANDANGAN HUKUM ISLAM TERHADAP PUTUSAN PENGADILAN NEGERI PADANG NOMOR: 69/PDT.G/2009/PN.PDG}

Sebelum membicarakan tentang pandangan hukum Islam terhadap putusan Pengadilan Negeri Padang Nomor: 69/Pdt.G/2009/PN.Pdg., perlu ditegaskan kembali bahwa meskipun hibah wasiat tidak terdapat dalam literatur hukum Islam, namun ia memiliki kedudukan yang sama dengan wasiat dalam hal pelaksanaannya. Oleh karena itu, untuk memudahkan dalam memahami sub topik ini, maka selanjutnya hibah wasiat di sini akan disebut dengan istilah wasiat.

Beranjak dari penyelesaian perkara hibah wasiat di Pengadilan Negeri Padang, terdapat dua hal yang perlu dikaji berdasarkan hukum Islam, yaitu perihal pemberian hibah wasiat kepada ahli waris dari penerima sah wasiat, dan mengenai pemberian hibah wasiat melebihi $1 / 3$ dari harta peninggalan pewaris, yaitu sebanyak $50 \%$. Untuk mendapatkan kesimpulan dari dua hal tersebut dalam pandangan hukum Islam, maka perlu dikaji terlebih dahulu fakta-fakta sebagai berikut:

Wasiat Batal Apabila Penerima Wasiat Telah Meninggal Terlebih Dabulu dari Pewasiat

Jumbur ulama berpendapat bahwa wasiat batal apabila penerima wasiat telah meninggal dunia terlebih dari pewasiat. Alasannya adalah bahwa wasiat merupakan pemberian, dan pemberian tersebut telah diperuntukkan untuk penerima wasiat. ${ }^{30}$ Sehingga apabila penerima wasiat meninggal

30 Wahbah Al-Zuhailī, al-Fiqh al-Islāmì wa Adillatuh, vol. VIII, (Beirut: Dār al-Fikr, 1985), 116. Lihat juga Abū Muhammad 'Abdullah ibn Aḥmad ibn Muhammad ibn Qudāmah al-Maqdisī, al-Mughnī, vol. VIII, 413. Lihat juga Imām 'Alāuddīn Abī Bakr ibn Mas'ūd, Badä'i al-Sanāi’ fì Tartīb al-Syarāi', vol. X, 594 terlebih dahulu, maka akad wasiat menjadi batal dengan sendirinya.

Berdasarkan hal ini terlihat bahwa dalam hukum Islam tidak ada istilah penggantian untuk penerimaan harta yang telah diwasiatkan. Harta tersebut kembali berstatus harta peninggalan dari pewasiat yang kemudian mesti dibagikan kepada ahli waris yang berhak. Dengan demikian, pemberian wasiat kepada ahli waris penerima hibah pada perkara Nomor: 69/Pdt.G/2009/PN.Pdg., tidak sesuai dengan hukum Islam dan semestinya harus dialihkan kepada status waris.

Wasiat Tidak Diperbolebkan Kepada Abli Waris, Kecuali Seluruh Abli Waris Menyetujui

Ulama sepakat bahwa tidak boleh berwasiat kepada ahli waris, kecuali dalam kondisi seluruh ahli waris menyetujui hal tersebut. Hal ini berdasarkan hadis Rasulullah SAW., sebagai berikut:

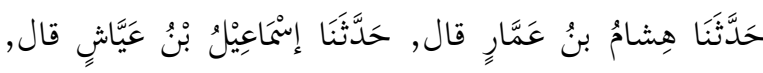

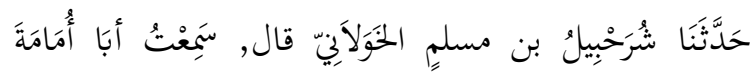

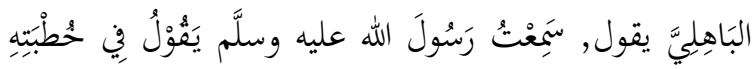

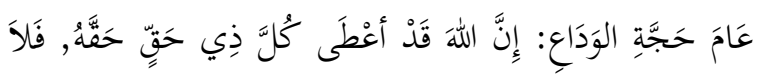

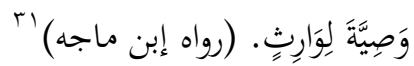

"Telah menceritakan kepada kami Hisyam ibn 'Ammär ia berkata, telah menceritakan kepada kami Ismäil ibn 'Abbās ia berkata, telah menceritakan kepada kami Syurahbill ibn Muslim al-Khawalāni ia berkata, aku mendengar ayah Umämah al-Bābilī berkata, aku mendengar Rasulullab SAW., bersabda pada saat haji wada': 'Sesunggubnya Allab telah memberikan masing-masing orang baknya, maka tidak ada harta wasiat untuk abli waris." (HR. Ibn Mäjah)

Dan hadis lainnya yang berbunyi sebagai berikut:

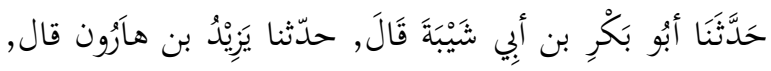

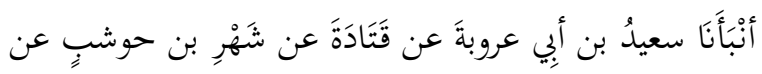

31 Abī Abdullāh Muhammad ibn Yazīd alQazwainī Ibn Mājah, Sunan Ibn Mājah, (Riyaụ: Maktabah al-Ma’̄arif, 1417 H), 461 


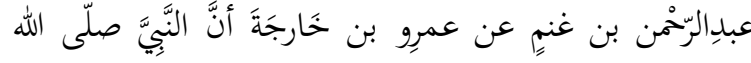

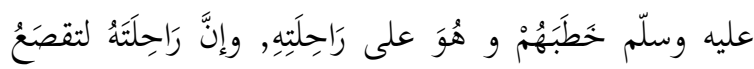

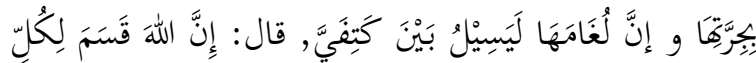

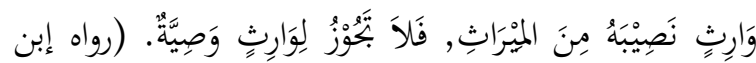
ماجه (rr

"Telah mengatakan kepada kami Abū Bakr ibn Syaibah ia berkata, telah mengatakan kepada kami Yazid ibn Härün ia berkata, telah menceritakan kepada kami Sa'ìd ibn Abì 'Arübah dari Qatādab dari Syabr ibn Ausyab dari 'Abd al-Rabman ibn Ghanam dari 'Amri ibn Khärijah bahwasanya Nabi $S A W$., berkhutbah di hadapan mereka dan beliau sedang berada di atas kendaraan (berupa unta) yang sedang mengunyah makanan, sementara air ludahnya mengalir di antara kedua babuku, beliau bersabda: 'Sesunggubnya Allah telah membagi harta warisan sesuai bagian masing-masing abli waris, sehingga abli waris tidak boleh mendapatkan wasiat." (HR. Ibn Mäjah)

Hadis Rasulullah SAW., di atas pada dasarnya merupakan landasan bagi Jumhur Ulama, yang dalam hal ini adalah Abū Bakr ra., Alī ibn Abī Thalib, Ibn 'Umar dan Abū Mūsā menyebutkan bahwa ayat 180 surat al-Baqarah dan ayat 106 surat al-Māidah telah di-nāsakeh oleh ayat 11, 12, dan 176 surat al-Nisāà. Artinya, tidak ada lagi wasiat bagi orang-orang yang disebutkan dalam surat al-Maidah ayat 160, karena bagi mereka telah diperuntukkan warisan sebagaimana yang diatur dalam ayat 11, 12, dan 176 surat al-Nisā’’

Pada fakta hukum dalam perkara hibah wasiat Nomor: 69/Pdt.G/2009/PN.Pdg., jelas telah terjadi sengketa di antara penerima wasiat terkait pelaksanaan wasiat yang telah dibuat. Oleh sebab itu, maka wasiatnya menjadi batal, baik untuk isteri pewasiat yang masih hidup, apalagi untuk saudara-saudara pewasiat yang telah meninggal lebih dahulu dari pewasiat.

Apabila para pihak tetap ingin menyelesaikan perkara tersebut, maka cara penyelesaian yang tepat menurut hukum Islam adalah dengan membaginya sesuai dengan

32 Abī Abdullāh Muhammad ibn Yazīd alQazwainī Ibn Mājah, Sunan Ibn Mājah, 460-461 ketentuan waris. Sebelum membagi harta warisan tersebut, harus diawali dengan pembagian harta bersama antara tergugat I yang merupakan isteri sah pewasiat/pewaris dengan pewasiat/pewaris. Kemudian dikeluarkan kewajiban-kewajiban lainnya atas nama pewaris, untuk selanjutnya dilakukan membagian harta sesuai dengan ketentuan waris, yaitu diperuntukkan bagi isteri pewaris sebanyak $1 / 4$ dari harta warisan, dan untuk anak-anak dari saudara-saudara kandung pewaris sebagai ahli waris pengganti dengan kedudukan sebagai aṣabah (menghabiskan sisa harta), dengan catatan bagian tersebut tidak melebihi dari bagian ahli waris sederajat dengan yang diganti. ${ }^{33}$

Putusan Nomor: 69/Pdt.G/2009/PN.Pdg., Telah Berkekuatan Hukum Tetap dan Tidak Ada Upaya Hukum Apapun dari Para Pibak Untuk Membantabnya

Berdasarkan fakta hukum setelah putusan dibacakan tidak terdapat bantahan dari para pihak. Para pihak tidak satupun mengajukan upaya hukum untuk menyanggah putusan hakim dalam perkara hibah wasiat Nomor: 69/Pdt.G/2009/PN.Pdg. Artinya, para pihak setuju dengan putusan hakim. Tergugat menerima secara sukarela putusan hakim mengenai penyerahan $50 \%$ saham milik Pewaris kepada Para Penggugat sebagaimana yang termaktub di dalam Akta Wasiat.

Namun, dalam ketentuan hukum Islam Pemberian wasiat lebih dari $1 / 3$ harta peninggalan jelas keliru. Hal ini berdasarkan hadis Rasulullah SAW., sebagai berikut:

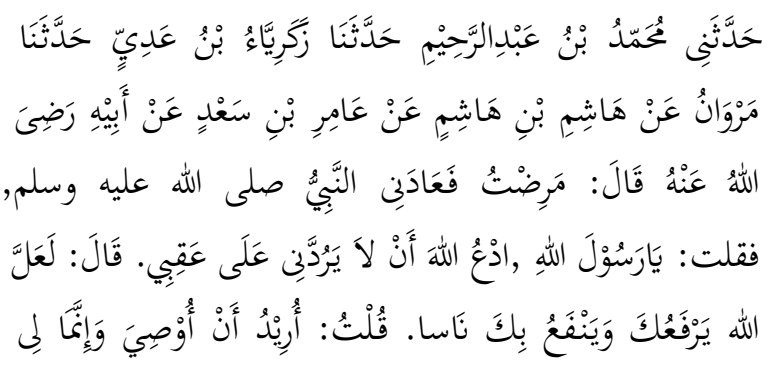

33 Ketentuan mengenai bagian ahli waris pengganti diatur dalam pasal 185 ayat (1) dan (2) KHI. 


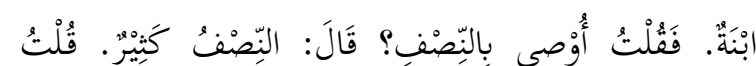

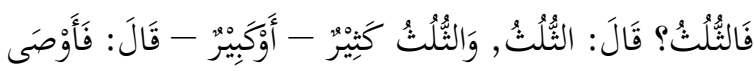

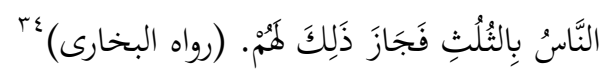

"Telah bercerita kepadaku Mubammad ibn 'Abd alRahìm, telah menceritakan kepada kami Zakariyya' ibn 'Adiy, telah menceritakan kepada kami Marwān dari Hāsyim ibn Hāsyim dari 'Āmr ibn Sa'ad dari ayahnya ra., ia berkata: Aku sakit, lalu Nabi $S A W$., menjenguk.ku. Kemudian aku katakan: Ya Rasulullah, mohonkanlah kepada Allah agar Dia tidak mengembalikan aku kepada keadaan sebelumnya (negeri kafir). Beliau bersabda: Semoga Allah mengangkat derajatmu dengan memberikan manfaat kepada manusia melalui dirimu. Aku berkata: Aku ingin berwasiat, sedangkan aku memiliki seorang anak perempuan. Maka aku bertanya apakah aku boleh berwasiat dengan setengah hartaku? Beliau bersabda: Setengah itu banyak. Aku tanyakan lagi: Sepertiganya? Beliau bersabda: Ya, sepertiga. Sepertiga itu banyak atau besar. Dia (Sa'ad) berkata: Maka kemudian orang-orang berwasiat sepertiga dan beliau (Rasulullab $S A W$ ) membolebkannya." (HR. Bukhārī)

Terkait fakta yang pertama disebutkan bahwa wasiat batal apabila penerima wasiat meninggal lebih dahulu dari pewasiat, dan itu mutlak adanya berdasarkan pendapat Jumhur Ulama. Namun, tidak ditemukan penjelasan yang rinci dalam kitab fikih mengenai apakah pembatalan tersebut berlaku untuk seluruh penerima wasiat, atau hanya batal bagi penerima wasiat yang telah terlebih dahulu meninggal dunia. Untuk hal ini, rasanya perlu meninjau kembali kepada kitab fikih yang memuat ketentuan tersebut, yaitu Kitab al-Fiqh al-Islami wa adillatuh karangan Wahbah alZuhailī, Kitab al-Mughni karangan Ibn alQudāmah, dan Kitab Badāi al-Sanāì fì Tartīb al-Syaräi’ karangan al-Kasānī.

Wahbah al-Zuhailī dalam Kitab al-Fiqh al-Islämi wa Adillatub mengemukakan salah satu alasan batalnya wasiat adalah meninggalnya penerima waris sebelum meninggalnya pewasiat membatalkan wasiat berdasarkan

${ }^{34} \mathrm{Abū}$ Abdullah Muhammad ibn Ismāīl alBukhārī, al-Jamì’ al-Ṣaḥihn, 287 kesepakatan mazhab yang empat (Syafi'i, Maliki, Hanafi, Hanbali). ${ }^{35}$ Adapun dalam Kitab al-Mughnì karangan Ibn al-Qudāmah disebutkan bahwa apabila meninggal penerima wasiat sebelum meninggalnya pewasiat, maka batallah wasiat tersebut. ${ }^{36}$ Redaksi serupa juga dipaparkan oleh al-Kasān̄̄ dalam kitabnya Badä'i al-Sanäi' fì Tartīb al-Syaräi', yaitu wasiat batal dengan meninggalnya penerima wasiat sebelum meninggalnya pewasiat, karena akad wasiat teruntuk bagi penerima wasiat (yang lebih dahulu meninggal dunia tersebut), bukan untuk selain darinya. ${ }^{37}$

Berdasarkan ketiga kitab tersebut penulis memahami bahwa wasiat batal hanya untuk penerima wasiat yang lebih dahulu meninggal dunia dari pewasiat.Hal ini

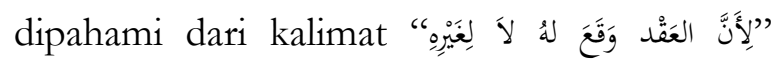
dalam kitab Badāi al-Sanāi’ karangan al-Kasānī, yaitu "karena akad wasiat teruntuk bagi penerima wasiat (yang lebih dahulu meninggal dunia tersebut), bukan untuk selain darinya". Artinya, akad wasiat yang batal adalah yang berkaitan dengan hak penerima wasiat yang telah meninggal lebih dahulu. Sedangkan bagi penerima wasiat lainnya yang masih tetap mendapatkan haknya sesuai dengan akad wasiat tersebut, karena telah diperuntukkan baginya.

Berdasarkan hal tersebut di atas, maka dapat disimpulkan bahwa ketika beberapa orang berstatus sebagai penerima wasiat, namun kemudian salah satu atau beberapa orang dari penerima wasiat meninggal lebih dahulu dari pewasiat, maka bagi orang yang meninggal dunia tersebut hak wasiatnya batal. Adapun bagi penerima wasiat lainnya yang masih hidup, untuk mereka hak wasiat sesuai

35 Wahbah Al-Zuhailī, al-Fiqh al-Islāmì wa Adillatuh, 116

36 Abū Muhammad 'Abdullah ibn Aḥmad ibn Muhammad ibn Qudāmah al-Maqdisī, al-Mughnī, vol. VIII, 413

37 Imām 'Alāuddīn Abī Bakr ibn Mas'ūd alKasānī al-Hanafī, Badā’i al-Ṣanāì fì Tartīb al-Syaräi’, 594 
dengan apa yang telah termuat dalam Akta Wasiat.

Selanjutnya, berkaitan dengan fakta kedua dan ketiga, dengan tanpa mengabaikan ketentuan pada fakta pertama, maka secara ketentuan hukum Islam wasiat bagi para penggugat telah batal dengan sendirinya. Meskipun dalam fakta hukumnya tergugat I dengan sukarela menerima putusan hakim Pengadilan Negeri Padang. Hal ini terbukti dengan tidak adanya bantahan terhadap putusan tersebut hingga berkekuatan hukum tetap.

Berdasarkan apa yang telah diuraikan di atas, dapat ditarik benang merah dari penyelesaian perkara hibah wasiat Nomor: 69/Pdt.G/2009/PN.Pdg., dalam perspektif hukum Islam sebagai berikut:

Pertama, pemberian wasiat kepada para penggugat adalah batal, karena mereka bukan penerima sah wasiat sebagaimana yang termaktub dalam Akta Wasiat Nomor XXX Tahun 2000. Mereka hanya berstatus sebagai ahli waris pengganti dari saudara-saudara kandung pewasiat yang telah lebih dahulu meninggal daripada pewasiat.

Meskipun tergugat I sebagai ahli waris lainnya tidak membantah dalam artian menyetujui, namun hal tersebut dibatalkan oleh hal-hal berikut yang saling berkaitan dan tidak dapat terpisahkan satu sama lain, yaitu wasiat bagi penerima wasiat yang telah meninggal dunia lebih dahulu dari pewasiat telah batal menurut pendapat Jumhur Ulama, dan wasiat bagi ahli waris tidak diperbolehkan dalam hukum Islam berdasarkan ketentuan Hadis Nabi SAW., dalam riwayat Ibn Mājah yang telah dikemukakan di atas.

Kedua, pemberian 50\% kepemilikan saham sebagai wasiat dan dua bidang tanah kepada tergugat I dalam perkara Nomor: 69/Pdt.G/2009/PN.Pdg., telah melanggar ketentuan hukum Islam. Meskipun terdapat pengecualian dalam keadaan seluruh ahli waris menyetujui, namun dalam perkara tersebut jelas telah terjadi perselisihan di antara para penggugat dan tergugat I yang merupakan ahli waris dari pewaris hingga perkara ini diajukan ke pengadilan. Selain itu, yang terpenting adalah wasiat untuk ahli waris adalah tidak sah, sehingga dengan demikian batallah hak serta kadar wasiat yang diperuntukkan untuk tergugat I yang merupakan isteri (ahli waris) dari pewaris/pewasiat.

Berdasarkan hal tersebut di atas terlihat jelas bahwa penyelesaian hibah wasiat dalam perkara Nomor: 69/Pdt.G/2009/PN.Pdg., bertentangan dengan ketentuan hukum Islam yang seharusnya dipraktekkan oleh orangorang beragama Islam. Perkara tersebut memang berakhir tanpa adanya upaya hukum yang menandakan semuanya menerima putusan hakim Pengadilan Negeri Padang Kelas I.A dalam perkara tersebut. Namun, perkara peralihan harta dari orang yang telah meninggal dunia kepada orang yang masih hidup dalam Islam merupakan sebuah pertanggungjawaban secara vertikal antara manusia dengan Allah SWT., dan secara horizontal antara sesama manusia.

\section{KESIMPULAN}

Berdasarkan uraian-uraian di atas berkenaan dengan penelitian ini, maka dapat diambil beberapa kesimpulan. Argumentasi majelis hakim Pengadilan Negeri Padang yang memeriksa dan memutuskan perkara hibah wasiat Nomor: 69/Pdt.G/2009/PN.Pdg., terkait kewenangan absolut pengadilan, hakim meyakini bahwa putusan tersebut sudah benar adanya berdasarkan tekstual pasal 49 UU Nomor 3 Tahun 2006 tentang Peradilan Agama yang sama sekali tidak mencantumkan "hibah wasiat" sebagai kewenangan dari Peradilan Agama. Sebaliknya, konsep hibah wasiat terpapar jelas di dalam KUH Perdata yang merupakan salah satu sumber hukum bagi Peradilan Umum.

Kemudian sebagai perbandingannya, hakim Pengadilan Agama menyebutkan bahwa 
hibah wasiat adalah wasiat itu sendiri, terlebih pihak yang berperkara merupakan orang-orang beragama Islam. Sehingga perkara tersebut seharusnya merupakan kewenangan Peradilan Agama, bukan Peradilan Umum.

Adapun berkenaan dengan pelaksanaan perkara hibah wasiat Nomor: 69/Pdt.G/2009/PN.Pdg., majelis hakim terkait juga meyakini bahwa putusan tersebut sudah tepat adanya. Poin pentingnya adalah pada saat Akta Wasiat dibuat, para penerima wasiat tersebut sudah ada, meskipun pada saat pelaksanaannya penerima wasiat ternyata lebih dahulu meninggal dunia dari pewasiat. Selain itu, hibah wasiat memang harus ditunaikan apa adanya sesuai dengan yang telah dituliskan dalam akta wasiat.

Penyelesaian perkara hibah wasiat Nomor: 69/Pdt.G/2009/PN.Pdg., dalam pandangan hukum Islam dapat dilihat dari dua aspek, yaitu aspek pemberian wasiat kepada ahli waris dari penerima wasiat sah, dan pemberian $50 \%$ kepemilikan saham sebagai wasiat dan dua bidang tanah kepada tergugat I dari harta peninggalan pewasiat.

Untuk aspek pemberian wasiat kepada ahli waris dari penerima wasiat sah, hal ini batal menurut ketentuan hukum Islam. Alasannya adalah karena karena orang tua para penggugat sebagai penerima wasiat yang sah telah meninggal dunia lebih dahulu dari pewasiat, dan yang terpenting adalah wasiat kepada ahli waris adalah batal. Telah jelas dalam hal ini para penggugat berkedudukan sebagai ahli waris.

Adapun aspek pemberian wasiat lebih dari $1 / 3$ dari harta peninggalan pewasiat, yaitu $50 \%$ kepemilikan saham sebagai wasiat dan beberapa bidang tanah kepada tergugat I adalah tidak sah. Alasannya adalah karena melebihi $1 / 3$ harta pewasiat, dan pada kenyataannya telah terjadi sengketa di antara ahli waris (para penggugat dan tergugat I). Kemudian, yang terpenting adalah wasiat kepada ahli waris (tergugat $\mathrm{I} /$ isteri pewasiat/pewaris) tidak diperbolehkan menurut ketentuan hukum Islam. 


\section{DAFTAR KEPUSTAKAAN}

al-Bāqī, Muhammad Fuād 'Abd.Mu'jam al-Mufahras li al-alfäz al-Qur'ān al-Karìm. Mesir: Maṭba'ah Dār al-Kutub al-Mișriyyah. $1364 \mathrm{H}$

al-Bukhārī, Abū Abdullah Muhammad ibn Ismā'īl.al-Jamì al-Ṣaḥihn. Vol. 2. Mesir: Maṭba'ah alSalafiyyah, $1403 \mathrm{H}$

Departemen Pendidikan Nasional. Kamus Bahasa Indonesia. Jakarta: Pusat Bahasa. 2008

HS, Salim. Pengantar Hukum Perdata Tertulis (BW). Cet-3. Jakarta: Sinar Grafika. 2005

Ibn Mājah, Abī Abdullāh Muhammad ibn Yazīd al-Qazwainī. Sunan Ibn Mājah. Riyaḍ: Maktabah al-Ma'ārif. $1417 \mathrm{H}$

Ibn Qudāmah, Abū Muhammad 'Abdullah ibn Aḥmad ibn Muhammad al-Maqdisī. al-Muqni' fì Figh al-Imām Ahmad ibn Hanbal al-Syaibānī. Jeddah: Maktabah al-Sawādī li al-Tauzì’. 2000

-----. al-Mughnì. Vol. VIII. Riyaḍ: Dār 'Ālim al-Kutub. 1997

al-Jazīrī, 'Abd al-Raḥmān. Kitāb al-Fiqh 'alā al-Mąāhib al-Arba'ah. vol. III. Beirut: Dār al-Kutub al'Ilmiyyah. 2002

al-Kasānī, Imām 'Alāuddīn Abī Bakr ibn Mas'ūd al-Hanafî. Badāi al-Ṣanäi' fì Tartīb al-Syaräi'. Vol. X. Beirut: Dār al-Kutub al-'Ilmiyyah. 2002

al-Kasnāwī, Abū Bakr ibn Husain. Aṣal al-Madārik: Syarh Irsyād al-Sälik fì Fiquh Imām al-A'immah Mālik. Vol. III. Beirut: Dār al-Fikr. tt

al-Mahallī, Jalāl al-Dīn. Syarhu Minhaj al-Tăalibìn. Vol. III. Kairo: Dār Ihyā’’ al-Kutub al-‘Arabī. tt

Mertokusumo, Sudikno. Mengenal Hukum: Suatu Pengantar. Yogyakarta: Liberty. 1996

Mu'arif, Moh. Syamsul. Perbandingan Wasiat dalam Perspektif Kompilasi Hukum Islam (KHI) dan Burgerlijk Wetboek (BW). Jurnal Tafaqquh. Vol.3 No.2. Desember 2015

Munawwir, Ahmad Warson. Kamus Arab-Indonesia. cet-14. ed-2. Surabaya: Pustaka Progressif. 1997

Sābiq, Syaikh Sayyid. Figh al-Sunnah. Vol. III. Beirut: Dār al-Fikr. 2007

Sari, I Gusti Ayu Putu Oka Cahyaning Mustika, et.al,. Peralihan Hak Atas Tanah Berdasarkan Hibah Wasiat oleh Pelaksana Wasiat. ACTA COMITAS: Jurnal Hukum Kenotariatan. Vol.III No.1. April 2018

Satori, Djam'an dan Aan Komariah. Metodologi Penelitian Kualitatif. Bandung: Alfabeta. 2009

Sunggono, Bambang. Metode Penelitian Hukum. Jakarta: Raja Grafindo Persada. 2005

al-Syarbainī, Syams al-Dīn Muhammad ibn al-Khațīb. Mughni al-Muhtāj. Vol. III. Beirut: Dār alMa'rifah. 1997

Syațā, Abū Bakr ibn Muhammad Zain al-'Ābidīn. I'ānah al-Ṭalibinn. Vol. 3. t.tp: Dār Iḥ̂ā' al-Kutub al-'Arabiyyah. tt

al-Zuhailī, Wahbah. al-Fiqh al-Islāmi wa adillatuh. Vol. VIII. Beirut: Dār al-Fikr. 1985

Salinan Putusan Pengadilan Negeri Padang Nomor: 69/Pdt.G/2009/PN.Pdg

Kitab Undang-undang Hukum Perdata (KUH Perdata)

Instruksi Presiden RI Nomor 1 Tahun 1991 tentang Kompilasi Hukum Islam

Undang-undang Nomor 2 Tahun 1986 tentang Peradilan Umum

Perubahan Pertama Undang-undang Peradilan Umum Nomor 8 Tahun 2004

Perubahan Kedua Undang-undang Peradilan Umum Nomor 49 Tahun 2009

Undang-undang Nomor 7 Tahun 1989 tentang Peradilan Agama

Perubahan Pertama Undang-undang Peradilan Agama Nomor 3 Tahun 2006

Perubahan Kedua Undang-undang Peradilan Agama Nomor 50 Tahun 2009

Undang-undang Nomor 14 Tahun 1970 tentang Kekuasaan Kehakiman

Perubahan Pertama Undang-undang Kekuasaan Kehakiman Nomor 35 Tahun 1999

Perubahan Kedua Undang-undang Kekuasaan Kehakiman Nomor 4 Tahun 2004

https://www.pn.padang.go.id 